\title{
Oral Cavity Leiomyoma
}

National Cancer Institute

\section{Source}

National Cancer Institute. Oral Cavity Leiomyoma. NCI Thesaurus. Code C5909.

A benign smooth muscle neoplasm arising from the oral cavity. It is characterized by the presence of spindle cells with cigar-shaped nuclei, interlacing fascicles, and a whorled pattern. 